\title{
遊離空腸による下咽頭・頸部食道の再建
}

\author{
久留米大学医学部耳鼻咽喉科学教室 (主任: 平野 実教授) \\ 田中信三, 平野実, 松岡秀隆 \\ 久留米大学医学部形成外科学教室 (主任: 田井良明教授) \\ 井上要二郎, 田 井良明
}

\section{FREE JEJUNAL AUTOGRAFT FOR PHARYNGOESOPHAGEAL RECONSTRUCTION}

\author{
SHINZO TANAKA, M.D., MINORU HIRANO, M.D. and HIDETAKA MATSUOKA, M.D.
}

Department of Otolaryngology - Head and Neck Surgery, Kurume University, Fukuoka

YOUJIRO INOUE, M.D. and YOSHIAKI TAI, M.D.

Department of Plastic Surgery, Kurume University, Fukuoka

The complications and swallowing functions were studied in eleven patients who had undergone free jejunal autograft reconstruction after total pharyngolaryngectomy and cervical esophagotomy. All patients have had advanced cancers of the hypopharynx or cervical esophagus. Fistulla was complicated in three patients $(27 \%)$, including one $(9 \%)$ who died of pneumonia. Death or graft necrosis was not complicated in perioperative period. There was no patient with stenosis. Radiation necrosis of the graft and skin occured six monthes after post-operative $60 \mathrm{~Gy}$ irradiation in one patient. Ten patients of 11 regained swallowing function. An oral diet was started between 9 and 50 post-operative days, with an average of 19 days. The duration of a diet was from 20 to 60 minutes (mean: 37 to 40 minutes). Five patients could take a normal diet, while the another five ate gluel or liquid food. The free jejunal graft reconstruction of pharyngoesophagus was highly safe reliability and an advantage in an early recovery of swallowing function, but it had some problems with regard to post-operative irradiation and swallowing.

Key words : 下咽頭頸部食道癌, 咽喉食摘, 遊離空腸移植 合併症, 曣下機能

$$
\text { A } 94-0192-53324
$$

\section{はじめに}

下咽頭癌や頸部食道癌のうち 3 期・4期の進行癌に 対しては両側頸部郭清, 咽頭喉頭全摘食道切除（咽喉 食摘）術と共に化学療法や放射線照射を併用する場合 が多い，従って，切除後の咽頭食道の再建には，血行 不全の生じない安全な方法であることの他に，䀣下機 能障害が少なく全身状態が良好に保たれること, 術後
の併用治療に対しても安全性が高いことが望まれる。 当耳鼻咽喉科では消化器外科, 形成外科とチームを組 み, 1989年 7 月より 90 年 2 月までの間に, 下咽頭・頸 部食道癌の咽喉食摘例11症例に対し遊離空腸に上る再 建を行った。これらの症例について術後の合件症と捸 食に関する経過を報告し, 遊離空腸による咽頭食道再 建法の女全性と德下機能について検討を加える。 


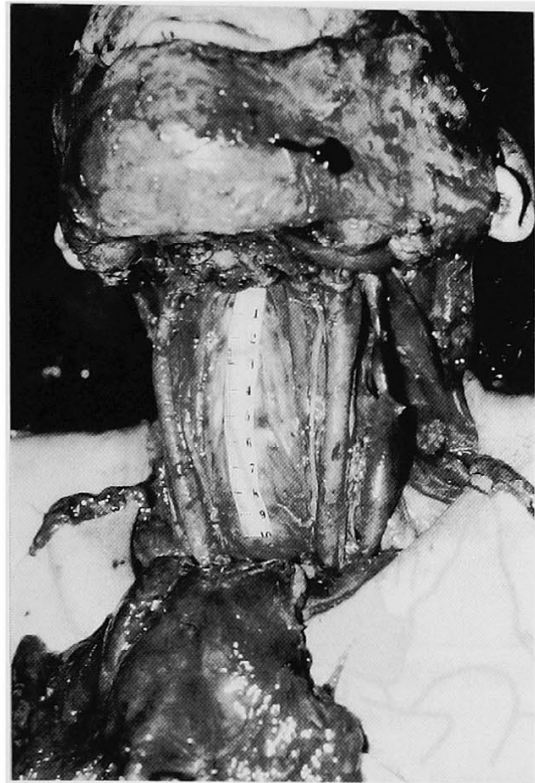

図 1 両側頸部郭清と咽頭喉頭全摘食道切除術 （食道切離前）

\section{手術法と対象}

図 1 のごとくエプロン状の皮膚切開で両側の頸部郭 清と咽喉食摘術を施行した。頸部郭清は両側とも顎下 腺，甲状腺を含め上綐隔の気管傍まで行い，一側の内 頸静脈を保存した，遊離空腸との血管吻合のために一 側の外頸静脈と頸横動脈を保存した。咽喉食摘は健常 部を $1.5 〜 2 \mathrm{~cm}$ 含めて行った.

次に，腹部正中皮膚を緹に切開し開腹した。図 2 の ごとく空腸を栄養する腸間膜動静脈の走行を確認し, 図 3 のごとく腸間膜を含めて空腸を切除した。この遊 離空腸を咽頭, 食道の切断端に図 4 のように吻合した. すなわち，空腸がたるまないように咽頭断端と空腸の 口腔側, 食道の断端と空腸の肛門側を共に端側に吻合 し, 空腸の両側端を切離, 縫合して短い盲端を作った. 咽頭・食道と空腸を端側吻合したのは端々吻合より空 腸吻合部の血行がよいと考えられたからである. 最後 に, 微小血管手術を用いて遊離空腸の栄養動静脈と頸 横動脈・外頸静脈を吻合した。

術後に移植空腸の生着をモニターするため, 空腸を 覆う前頸部皮膚に約 $5 \mathrm{~mm}$ の切開を加え, 空腸の色調 をみる観察空とした。術後 24 時間は 3 時間毎に, それ 以後は 6 時間毎に観察を行い, 術後 4,5 日目に閉鎖 した。また, 術後 2 週間は直視下またはファイバース コープを用いて移植空腸粘膜の観察を頻回に行った.

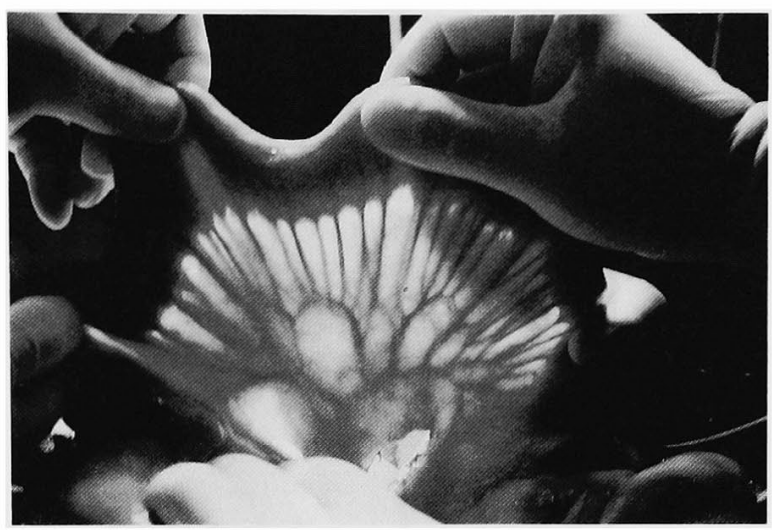

図 2 空腸を栄養する腸間膜動静脈の透光像

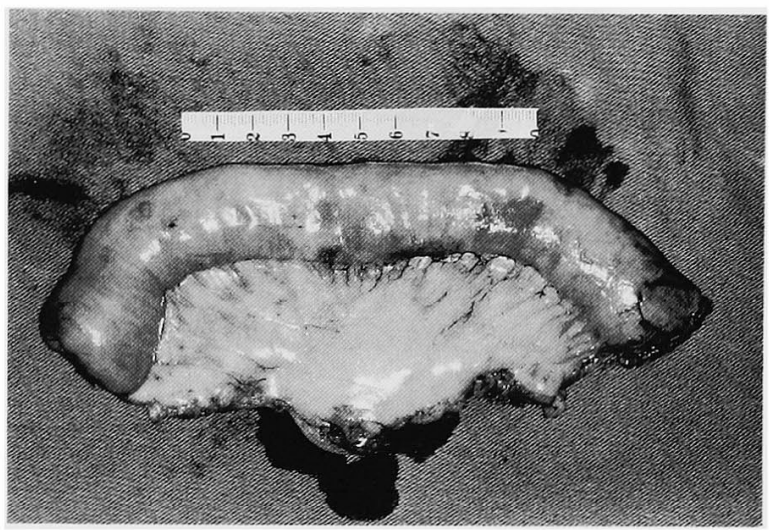

図 3 遊離した空腸と腸間膜

術後数日間は中心静脈栄養とし，その後は経管栄養 に替えた。術後 1 週間以上過ぎた時点で食道透視を施 行し，㾇孔がなく嚥下可能な状態が確認されれば経口 摂食を開始した。

以上の手術を施行した下咽頭・頸部食道癌の症例を 表 1 に示す，11症例中 10 例が下咽頭癌， 1 例が頸部食 道癌であり，す心゙て扁平上皮癌であった。年齢は31歳 から83歳まで, 男性10名, 女性 1 名であった。 $\mathrm{T}$ 分類 では T 3 が 5 例, T 4 が 6 例で, 下咽頭癌では全例に頸 部リンパ節転移が認められた。遠隔転移例はなかった。 病期分類では 3 期が 2 例， 4 期が 9 例であった。症例 3では胃癌もあったため胃业全摘術を同時に行った。 また, 症例 2 では遊離空腸をループ型に吻合した。

\section{結果}

1. 遊離空腸再建例の術後経過 表 2 に各症例の術後経過を示す 11例全例で遊離空腸は良好に生着し，いずれの例に 

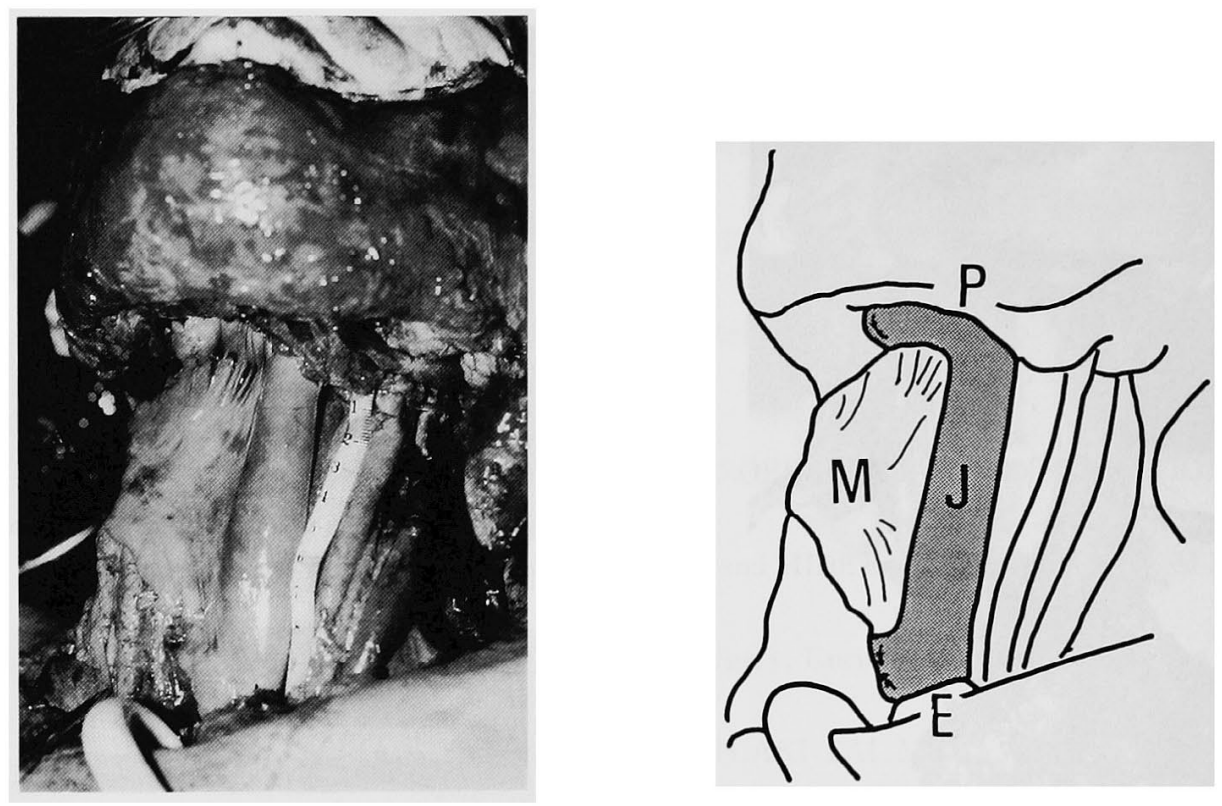

図 4 遊離空腸と咽頭，食道との吻合術

右イラストの $\mathrm{J}$ は空腸を, $\mathrm{M}$ は腸間膜を, $\mathrm{P}$ は咽頭断端を, $\mathrm{E}$ は食道断 端を示す.

表 1 遊離空腸による再建症例

(89年 7 月 90 年 2 月)

\begin{tabular}{|c|c|c|c|c|c|c|c|}
\hline 番号 & 氏名 & 年齢 & 性 & 患側 & 部 位 & TNM 分類 & 病期 \\
\hline $\mathrm{HPl}$ & M.O. & 54 & 男 & 右 & 梨状陌凹 & $\mathrm{T} 4 \mathrm{~N} 1 \mathrm{M} 0$ & 4 \\
\hline HP2 & K.N. & 72 & 男 & 右 & 梨状陌山 & $\mathrm{T} 4 \mathrm{~N} 2 \mathrm{CM} 0$ & 4 \\
\hline HP3 & S.U. & 83 & 男 & 右 & 梨状陥凹 & $\mathrm{T} 4 \mathrm{~N} 2 \mathrm{CM} 0$ & 4 \\
\hline $\mathrm{HP} 4$ & S.Y. & 52 & 男 & 左 & 輪状後部 & T3N2CM0 & 4 \\
\hline HP5 & A.Y. & 66 & 男 & 右 & 梨状陌凹 & T3N2CM0 & 4 \\
\hline HP6 & K.I. & 61 & 男 & 右 & 梨状陥凹 & $\mathrm{T} 3 \mathrm{~N} 1 \mathrm{M} 0$ & 3 \\
\hline HP7 & A.F. & 62 & 男 & 右 & 梨状陥凹 & T3N2AM0 & 4 \\
\hline HP8 & W.H. & 73 & 男 & 右 & 梨状陥凹 & T3N2BM0 & 4 \\
\hline HP9 & S.M. & 31 & 男 & 左 & 梨状陌凹 & T4N3 M0 & 4 \\
\hline HP10 & H.K. & 63 & 男 & 右 & 梨状陥凹 & T4N1 M0 & 4 \\
\hline $\mathrm{CE} 1$ & I.M. & 64 & 女 & 左 & 頸部食道 & T4N0 M0 & 3 \\
\hline
\end{tabular}

も再建部の血行不全や壊死は見られなかった。

術後の合併症では咽頭皮膚㾇が 2 例, 食道皮膚瘦と 著明な舌・顔面浮腫が各 1 例ずつあった。咽頭皮膚瘻 の 1 例（HP1）は創部の血腫のために生じ， 7 週間で 自然閉鎖した。他の 1 例（HP9）は頸動脈への癌浸潤 が疑われたために術前照射を行った例で, 術後 3 週目 に瘦孔を生じ，2力月目に頸部の癌再発を来した，食 道皮膚瘦の例 (HP3) は胃要全摘術を併用した症例で, 術後に低アルブミン血症と肺水腫を来し 3 力月後に肺
炎のために死亡した。

術後照射は 11 例中 3 例に $60 \mathrm{~Gy}, 6$ 例に $30 \mathrm{~Gy}$ を行っ たが，60Gy 照射の 1 例 (HP4) に遅発性放射線壊死が 生じた.この例は照射終了後 6 力月目に移植空腸のほ ぼ全域と前頸部皮膚が壊死に陥り，DP 皮弁による皮 䖉欠損部の再建を要した。

各症例の観察期間はまだ短いが，1990年 6 月20日の 時点で11例中 7 例が非担癌生存中である.

2. 遊離空腸再建例の攝食経過 
表 2 遊離空晹に上る再建症例 $\sigma$ 術後経過（89年 7 月〜90年 6月）

\begin{tabular}{|c|c|c|c|c|c|}
\hline $\begin{array}{l}\text { 症例 } \\
\text { 番号 }\end{array}$ & $\begin{array}{l}\text { 遊離空晹 } \\
\text { 生着 }\end{array}$ & 合 併 症 & 再発, 軾移 & \multicolumn{2}{|c|}{$\begin{array}{l}\text { 俊 } \\
(1990.6 .20 . \text { 現在) }\end{array}$} \\
\hline $\mathrm{HPl}$ & 艮好 & 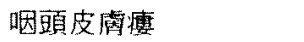 & & 非担癌生存 & 12力月 \\
\hline $\mathrm{HP} 2$ & 泉好 & & 肺転移 & 担癌生存 & 12 力月 \\
\hline $\mathrm{HP} 3 *$ & 良好 & 食道皮虞慺・肺炎 & & 合併症死 & 3 力月 \\
\hline $\mathrm{HP} 4$ & 良好 & 遅発性放射線壊死 ** & & 非担癌生存 & 11力月 \\
\hline HP5 & 良好 & & & 非担癌生存 & $10 力 月$ \\
\hline HP6 & 良好 & 舌・顔面浮腫 & & 非担癌生存 & 9 力月 \\
\hline HP7 & 良好 & & & 非担癌生存 & 9 力月 \\
\hline HP8 & 良好 & & 頸部再発, 肺転移 & 原病死 & 7 力月 \\
\hline HP9 & 良好 & 咽頭皮喉瘦 $* * *$ & 頸部再発 & 担癌生存 & 7 力月 \\
\hline HP10 & 良好 & & & 非担懆生存 & 6 力月 \\
\hline CEl & 良好 & & & 非担癌生存 & 6 力月 \\
\hline
\end{tabular}

*：胃癌の併発で霄垔全摘術を併用，**：照射 $(60 \mathrm{~Gy}$ ) 後 6 力月目 $* * *$ : 術前照射 $30 \mathrm{~Gy}$

表 3 遊離空腸による再建例の攝食に関する経過

\begin{tabular}{|c|c|c|c|c|c|c|c|c|c|}
\hline $\begin{array}{l}\text { 症例 } \\
\text { 番号 }\end{array}$ & $\begin{array}{c}\text { 経口摂食 } \\
\text { 開始日 }\end{array}$ & $\begin{array}{l}\text { 摂食状態 } \\
\text { 調查日* }\end{array}$ & 内容 & 時間 & $\begin{array}{l}\text { 畺後 } \\
\text { 照射 }\end{array}$ & $\begin{array}{c}\text { 摄食状態 } \\
\text { 調查日** }\end{array}$ & 内容 & 時間 & $\begin{array}{l}\text { 術後 } \\
\text { 照射 }\end{array}$ \\
\hline HPl & 50 日後 & 226日後 & 粥食 & 20 分 & 後 & 344日後 & 䉼食 & 30 分 & 㣪 \\
\hline HP2 & 18日後 & 159日後 & 普通 & 60 分 & 後 & & & & \\
\hline \multicolumn{10}{|l|}{$\mathrm{HP} 3$} \\
\hline $\mathrm{HP}_{4}$ & 9 日後 & 197日後 & 普通 & 20分 & 後 & & & & \\
\hline HP5 & 15日後 & 176日後 & 普通 & 30 分 & 後 & 295日後 & 普通 & 30分 & 後 \\
\hline HP6 & 42 日後 & 172日後 & 楼食 & 50 分 & 後 & 284日徭 & 粥食 & 60 尔 & 後 \\
\hline HP7 & 11日後 & 149日後 & 獭食 & 30 分 & 後 & 267日徭 & 粥食 & 30 分 & 後 \\
\hline HP8 & 11日後 & 111日娞 & 普通 & 50 分 & 前 & & & & \\
\hline HP9 & 12日後 & 18日徭 & 粥食 & 40分 & 前 & & & & \\
\hline HP10 & 10日偻 & 65日後 & 粥食 & 30 分 & 中 & 183日後 & 䉼食 & 304 & 後 \\
\hline CE1 & 12日後 & 58日後 & 强食 & 40分 & 中 & 158日後 & 普通 & 60 分 & 後 \\
\hline 平均 & 19日後 & 133日後 & & 37 分 & & 255 日後 & & 40分 & \\
\hline $\mathrm{SD}$ & $14 日$ & 64日 & & 13 分 & & 65日 & & 14 分 & \\
\hline
\end{tabular}

\section{各症例の攝食に関する経過を表 3 に示す}

合併症死の例を除く 10例で術後 9 〜 50 日後, 平均 19 日後に経口摄食が開始された，呕頭皮虞瘦や舌・顔面 浮腫などの合併症のない7例では $9 \sim 18$ 日後, 平均 12 日後に開始された。

摂食状態の調查は90年 2 月（1回目）と90年6月(2 回目）に行われた１回目の調查時には10例が経口摄 食可能で普通食 4 例，䉼食 6 例であった。胃管栄盖や 点滴による補助栄韻を要する例はなかった。1回の攝 食に要する時間は20 60分, 平均37分であった。術後
経過日数と椇食状態の間には明らかな関係はなかっ た。また，放射線照射前または照射中と照射後の症例 間には摃食内容や摄食時間に明らかな違いは認められ なかった。2 回目の調查時では 6 例が経口椇食可能で, 提食時間は30〜60分，平均40分であった，摄食内容は 1 回目とほとんど変わらず，捸食時間はやや長くなつ た例はあるが全体としてははぼ不変であった。

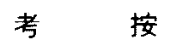

1）遊離空腸移植の安全性について 
表 4 遊離空腸による咽頭食道再建の合併症

\begin{tabular}{|c|c|c|c|c|c|c|c|}
\hline \multirow{2}{*}{ 報 告 者 } & \multirow{2}{*}{ 発表年 } & \multirow{2}{*}{ 対 象 疾 患 } & \multirow{2}{*}{ 症例数 } & \multicolumn{4}{|c|}{ 合 併 症 例 数 } \\
\hline & & & & 手術死 & 移植部壊死 & 瘦孔 & 狭窄 \\
\hline Gluckman $b^{21}$ & 1985 & 士に下咽頭癌 & 52 & - & 4 & 5 & 6 \\
\hline Biel $\check{5}^{3)}$ & 1987 & 下咽頭頸部食道癌 & 17 & 3 & 3 & 6 & 3 \\
\hline Schechter $5^{4)}$ & 1987 & 下咽頭頸部食道癌 & 17 & - & 3 & - & - \\
\hline Coleman $5^{51}$ & 1987 & 主に下咽頭頸部食道癌 & 88 & 5 & 10 & 28 & 6 \\
\hline Ferguson $5^{6}$ & 1988 & 下咽頭頸部食道癌 & 18 & 1 & 1 & 6 & 2 \\
\hline de Vries $5^{7)}$ & 1989 & 主に下咽頭頸部食道癌 & 17 & 0 & 2 & 4 & 4 \\
\hline 本報告 & 1990 & 下咽頭頸部食道癌 & 11 & $0(1) *$ & $0(1) * *$ & 3 & 0 \\
\hline
\end{tabular}

遊離空腸による咽喉食摘後の咽頭食道再建術は1957 年 Seidenberg" により初めて施行された。 その後の微 小血管吻合の技術的進歩に伴って遊離移植の安全性が 向上し, 咽頭食道再建に遊離空腸を用いることが次第 に多くなってきた。

比較的最近の報告では, 表 4 に示すごとく, 遊離空 腸を用いた咽頭食道再建術における合併症の頻度は手 術死が $0 \sim 18 \%$, 移植部壊死が $6 \sim 18 \%$, 瘦孔の合併 が10〜35\%，吻合部の狭窄が 7〜12\%である。また， 本報告では，遅発性放射線壊死例を除くと，手術死， 移植部壊死，㹨窄の例はなく，11例中 1 例 $(9 \%) に$ 肺炎による合併症死が，3例（27\%）に瘦孔が生じた のみであった。本症例では術後の経過期間が短いもの が多く, 今後, 遅発性の吻合部狭窄例が多くなる可能 性はあるが，移植した遊離空腸の壊死や手術死はこれ までの報告に比べて明らかに少なくなっている。また 㿉孔の発生も遊離空腸の血行障害や壊死に起因するも のはなかった，微小血管手術を用いた遊離空腸移植は これまで以上に安全に施行できるようになり，吻合血 管の血行不全やそれに伴う移植部の壊死はほとんど問 題にならなくなっていると言える。

下咽頭・頸部食道癌に対寸る術後の放射線療法は他

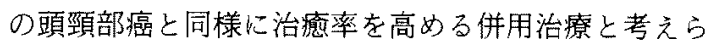
れる。しかしながら，一般に腸管は放射線障害性の高 い組織なので，移植した遊離空腸においては術後照射 の障害性が問題となる。本報告例では11例中 9 例に術 後照射を施行し，1例に放射線による遅発性の移植部 壊死が生じている。この症例は 60Gy 照射した 3 例中 の 1 例で，30Gy 照射した6 例には放射線障害はなか ったすすなわち，本例は遊離空晹再建例に対する術後 の高線量照射の危険性を示唆するものであり，照射の
（）*：合併症死例，（）**：晴発性放射線壊死例

線量と部位に注意して術後の放射線療法を行う必要が あると言える。

2）遊離空腸再建後の德下機能について

遊離空腸による咽頭食道再建例ではしばしば魷下機 能の低下が指摘されている。％の原因として，移植し た空腸の自律運動が食物の通過を遅延させることやや 中咽頭の合併切除で蜳下圧の低下が生じるこどなど が挙げられている。

しかしながら，下咽頭・頸部食道癌切除後の掑食・ 詈下状態を再建法別に比較した Schechter ら によると，遊離空腸例は胃管釣り上げ例より摂食内容 は少っているが DP 皮弁や大胸筋皮弁の例上り峙下 障害の程度が軽度である。また, Ferguson ら $^{6)}$, de Vries ら”の遊離空腸再建例では経口摂食開始がそれ ぞ机術後 $9 \sim 43$, 平均 17 日後, $6 \sim 27$, 平均 9 日後で あり，遊離空腸の利点として術後早期に経口で搷食で きることが指摘されている。

本報告例でも術後 $9 \sim 50$, 平均19日後に，合併症の ない例に限ると術後 $9 \sim 18$, 平均 12 日後に経口攝食が 開始されここれまでの報告例上同様に術後の経口掑食 は比較的早期に開始できた。また，摂食状態は普通食 また注粥食の食事内容で，1回の食事に要する時閒は $20 \sim 60$ 分, 平均 37 分〜 40分であった，食事内容や捸食 時間は必ずしも正常とは言えないが，日常生活に著し い支障を来すほどの曣下障害ではなかった。したがっ $\tau$, 下咽頭頸部食道癌切除後の遊離空腸再建法は, 軽 度の熳下障害㹥あるものの，早期に経口摂食が開始で きるという点で有用な方法であると考兄られる。

遊離空腸再建例の曖下機能に影響する因子として は, 咽頭・食道の切除範囲, 空腸と咽頭・食道の吻合 状態, 術後の放射線照射, 術後の経過日数などが挙げ 
られる。これらの内，術後照射と 1 年までの経過日数 は德下機能に大きく影響しないことが本報告例で示さ れた。すなわち，遊離空腸による咽頭食道再建後の與 下機能は切除範囲や空腸の吻合状態に大きく依存する と考えられ，術後に良好な罟下機能を得るためにはこ れらの因子と嚥下機能の関係を明らかにしていくこと が必要と思われる。

\section{まとめ}

下咽頭・頸部食道癌の㸶喉食摘術に遊離空腸を用い て咽頭食道を再建した11症例について術後の合併症と 掑食経過を報告した。

1. 合併症は11例中 1 例に肺炎による合併症死が， 3例に瘦孔が生じたが, 手術死や移植空腸の血行不全 による壊死例はなかった，術後放射線照射による移植 部壊死が 1 例に生じた。

2. 経口捸食は 9 50日, 平均19日後に開始された。

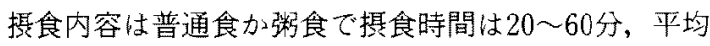
37分〜40分であった。

3.以上より, 遊離空腸に上る咽頭食道再建法は安 全性が高く䠢下機能の回復は早いが，術後照射の危険 性と摄食状態に問題があると考えられた。

\section{文献}

1) Seidenberg B, Rosenak SS,Hurwitt ES et al : Immediate reconstruction of the cervical esophagus by a revascularized isolated jejunal segment. Ann Surg 149: 162-171, 1959 .

2) Gluckman JL, McCafferty GJ, Black RJ et al : Complications associated with free jejunal graft reconstruction of the pharyngoesophagus, a multiinstitutional experience with 52 cases. Head Neck
Surg 7: 200-204, 1985.

3) Biel MA and Maisel RH: Free jejunal autograft reconstruction of the pharyngoesophagus, review of a 10-year experience. Otolaryngol Head Neck Surg 97: 369-375, 1987.

4) Schechter GL, Baker JW and Gilbert DA: Functional evaluation of pharyngoesophageal reconstructive techniques. Arch Otolaryngol 113: 4044. 1987.

5) Coleman JJ, Searles JM, Hester TR et al : Ten year experience with the free jejunal autograft. Am J Surg $154:$ 394-398, 1987.

6) Ferguson JL and DeSanto LW: Total pharyngolaryngectomy and cervical esophagectomy with jejunal autotransplant reconstruction, complications and results. Laryngoscope 98: 911-914, 1988.

7) de Vries EJ, Stein DW, Johnson JT et al : Hypopharyngeal reconstruction, comparison of two alternatives. Laryngoscope 99:614-617, 1989.

8）河野辰幸, 吉野邦英, 滝口 透, 山崎 繁, 遠藤光夫他: 遊䧸架腸移植に上る下咽頭頸部食道再建術における内 圧測定からふふな再建食道の運動機能. 日気食会報 37 ： 354-363， 1986.

9) 井上要二郎, 藤田博正, 田井良明, 掛川暉夫, 右田博文 他：遊離空腸移植を用いた下咽頭頸部食道再建後の暖 下障害について。形成外科 $32 ： 1037-1042 ， 1989$.

稿を終えるにあたり手術にご協力いただいた久留米大学 医学部第一外科教室, 藤田博正講師に深謝致します、本論文 の要旨は第14回日本頭頸部㯵富学会で発表した。

(1990年7月16日受稿 1990年9月26日受理)

别刷請求先 7830 久留米市旭町 67

久留米大学医学部耳鼻咽喉科学教室 田中信= 